

\title{
En busca de la modernidad deseada. Arquitectos españoles en EE. UU. en los años $\mathbf{5 0}$ Searching for the Desired Modernity.
} Spanish Architects in the USA in the 1950s

\author{
María del Pilar Salazar Lozano, Antonio José Cidoncha Pérez \\ Universidad de Navarra \\ Traducción Translation Proof-reading-service, por Megan Leonard
}

\section{Palabras clave Keywords}

Escuelas de Arquitectura, Estados Unidos, España, formación del arquitecto, años 50

Schools of Architecture, USA and Spain, architectural education, knowledge exchange, the 50s

\section{Resumen}

Los viajes que algunos arquitectos españoles realizaron a los Estados Unidos a mediados del siglo pasado constituyeron una importante fuente de información y conocimientos acerca de la arquitectura moderna. Entre todos ellos cabe destacar los que se hicieron como complementos a la formación en la profesión, en los que los arquitectos viajaron a los Estados Unidos para realizar estudios de posgrado en algunas de las más prestigiosas Escuelas de Arquitectura.

En este artículo se busca hacer una revisión general de las circunstancias en las que se dieron dichos viajes y un repaso de algunos de ellos. Con ello, se pretende aportar luces sobre la introducción del Movimiento Moderno en España a través de la educación de los arquitectos.
Abstract

The trips that Spanish architects made to the USA in the 1950s were a major source of the exchange of knowledge and information between the Spanish and American architecture of that time. Among them, we can highlight those done as a complement to the academic formation. Some of the Spanish architects who travelled to the USA entered post-graduate programs in some of the most prestigious schools of architecture.

The aim of this article is to provide an overview of the context and circumstances of those trips and to learn more about a few of them. We try to understand whether the Modern Movement was introduced in Spain through the academic formation, and at the same time, we try to explain the beginning of the cultural exchange in this field between Spain and the USA. 
Desde la Antigüedad, los viajes se han considerado fuentes insustituibles de conocimiento, confrontación con realidades diferentes y desarrollo del propio pensamiento. Los viajes exteriores, físicos, solo dejan una huella cuando van acompañados por el viaje interior de estudio y reflexión, con el análisis de la realidad encontrada. Los contrastes y el enfrentamiento con lo desconocido hacen que nos replanteemos lo ya conocido y propician el surgimiento de ideas y soluciones innovadoras.

La historia de los viajes de los arquitectos y la expansión de los estilos arquitectónicos por Europa ha quedado plasmada en las realizaciones que llevaron a cabo a su vuelta en sus lugares de origen o en aquellas ciudades que consideraban como destino final de estos trayectos. El atractivo que poseían las ciudades clásicas como centros de peregrinación de arquitectos (Alejandría, Atenas, Roma, París...) fue poco a poco sustituido parcialmente por las nuevas urbes modernas que se consolidan en el siglo xx, destacando entre todas ellas Nueva York.

Estados Unidos ya era en los años 50 un fascinante y poderosísimo centro de atracción. Ofrecía lo que en ese momento era más necesario y atractivo tras los horrores de la Segunda Guerra Mundial: una cultura del bienestar tecnológicamente desarrollada, en la que la Modernidad podía verse magnífica y victoriosamente encarnada. Además, Nueva York se había constituido como centro económico y también cultural, siendo considerada capital mundial del arte.

En el momento estudiado (mediados del siglo pasado) la huella que los viajes a Estados Unidos dejaron en sus protagonistas fue mucho mayor por las circunstancias del momento y el contraste con la situación en España. Los arquitectos que llegaron a Estados Unidos se encontraban con una realidad opuesta a la que vivían en su país; pasaban de una escasez de información sobre el Movimiento Moderno a una sobreabundancia:

“Te diría que a la gente que yo he conocido que estuvo allí por esas fechas nos marcó, con seguridad. Más adelante tal vez no tanto, porque en los años en

Since ancient times, the trips have been considered irreplaceable sources of knowledge, opportunities of confrontation with different realities, and development of thought. The physical trips leave a footprint only when they include an interior trip of study and reflection based on the analysis of what we find. The contrasts found and the confrontation with the unknown makes us rethink what we already know, and they promote the appearance of innovative ideas and solutions.

We can see the history of the trips that architects made reflected in the expansion of the architectonic styles all over Europe and in the buildings they made when they went back to their cities. The capacity of attraction that some classical cities had as pilgrimage centres for architects (Alexandria, Athens, Rome, Paris) has been gradually replaced with the new modern metropolis consolidated in the 20th Century, highlighting among them, New York.

The US in the 50s was already a fascinating and powerful centre of attraction. They offered what was looked for at that moment after the horrors of the Second World War: a technologically developed culture of well-being in which the people could see modernity magnificently and victoriously embodied. In addition, New York had arisen as an economical and cultural centre that was considered the Art world capital.

In the studied period (mid-20th Century), the footprint left by the trips to the USA on the travellers was huge because of the contrast between the situations in North America and Spain. The architects that arrived in the US found a reality 
que fui, veníamos de un desierto de comunicación; pero, como esto evolucionó deprisa, para quienes fueron 5 años después el contraste ya no era tan fuerte, las diferencias culturales, económicas y de todo tipo eran distintas". (1)

La política y los viajes. En 1945, el senador americano J. William Fulbright propuso invertir en intercambio educativo las divisas en moneda extranjera que tenía EE. UU. fruto de las deudas contraídas por países alrededor del mundo, siendo aprobado por el presidente Truman en 1946. Con ello se buscaba generar confianza y empatía con los sentimientos norteamericanos para crear aliados en cada país.

En España no se firmó el Acuerdo Fulbright hasta octubre de 1958. (Fig. 1) A partir de ese momento se empezaron a gestionar becas en diferentes ámbitos educativos para estudiantes, profesores e investigadores. Durante los años 60 se enviaron una media de 60 españoles por año para realizar estudios en los EE. UU. Provenían de diversas especialidades, no siendo la arquitectura una de las líneas prioritarias en ese momento, aunque sí que hubo varios becarios.

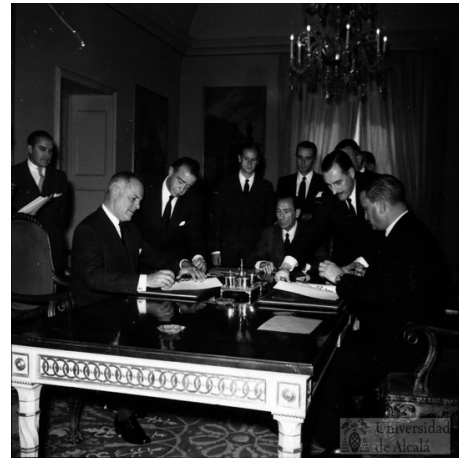

Fig. 1. Firma del Acuerdo Fulbright en octubre de 1958 en Madrid.

Hasta ese momento, y también después, los viajes de estudio que arquitectos españoles habían realizado a Estados Unidos habían sido subvencionados por diferentes entidades como la Academia de Bellas Artes de San Fernando, la Fundación del Amo, la Junta de Relaciones Culturales del Ministerio de Asuntos Exteriores, el Instituto Técnico de la Construcción y el Cemento, el Ministerio de Educación y Ciencia y otros organismos dependientes de la Administración pública.

La formación del arquitecto. Entre los viajes que realizaron arquitectos españoles a EE. UU. abe destacar los que se hicieron con una finalidad de ampliar conocimientos en alguna universidad americana. Ya eran arquitectos; pero decidieron completar su formación en algún tema de interés específico, aprovechando el alto nivel de la educación americana en algunos ámbitos. Haremos a continuación un breve repaso de la docencia en España y en Estados Unidos en ese momento, para luego ir enumerando brevemente algunos viajes que se realizaron en los años 50 .

completely different from the one they had left in their own country. They went from a scarcity of information about the Modern Movement to an overabundance.

"I could affirm that the people that I know that were in the USA at that moment were deeply touched by the experience. A few years later maybe not so much, but in the years I was there we came from a desert of information. That had a fast evolution, so for the ones who went five years later, the contrast was smaller; the cultural, economic, and social differences were different”. (1)

Politics and Trips. In 1945, the American senator J. William Fulbright proposed to invest in educational exchange the foreign currency that the USA had because of the debts of different countries. That was approved by President Truman in 1946. At the same time, they were trying to create a feeling of trust and empathy to have allies in every country.

The Fulbright Agreement was not signed with Spain until October 1958. (Fig. 1) From that moment, they started to give scholarships in different fields to students, professors, and researchers. During the 60s, about sixty Spaniards per year were studying in the USA. They came from different fields of specialization. Although Architecture was not one of the priorities, some architects were granted.

Until that moment and after it, the trips that the Spanish architects made to the USA were financed by entities like the Academia de Bellas Artes de San Fernando, Del Amo Foundation, the Junta de Relaciones Culturales, the Ministerio de 

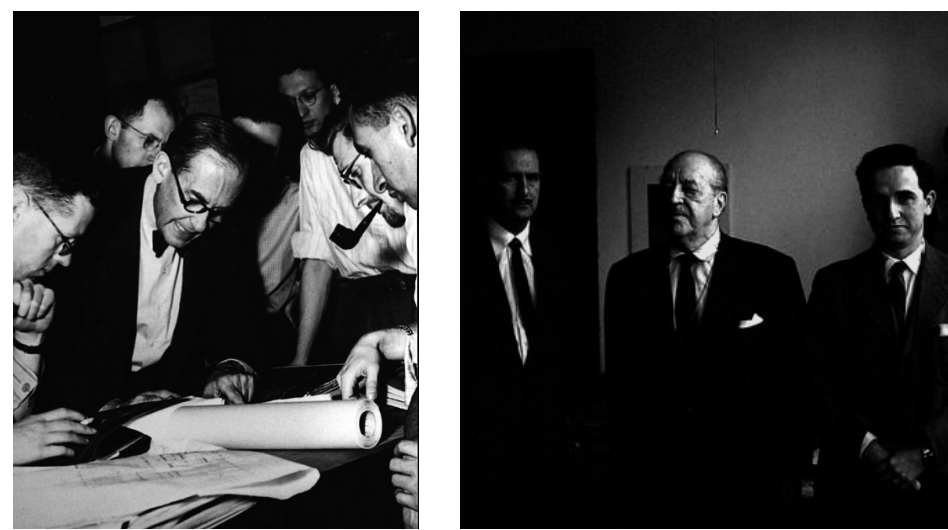

La enseñanza de la arquitectura a través de Escuelas de Arquitectura comenzó prácticamente a la vez en España y en EE. UU., a mediados del siglo XIX. La Escuela de Madrid abrió sus puertas en 1844 y la de Barcelona en 1875, siendo las únicas durante casi un siglo, hasta 1960, cuando se abre la Escuela de Sevilla. En EE. UU. las primeras Escuelas de Arquitectura, todas privadas, fueron las del Massachusetts Institute of Technology (1865), Cornell University (1871) y la University of Illinois (1873). Antes de despuntar el siglo Xx Estados Unidos ya contaba con once escuelas. No es hasta 1897 cuando surge la primera ley de registro de arquitectos en Illinois. Hasta ese momento no había entidad que supervisara la educación, formación y competencias de quienes en la práctica ejercían como arquitectos.

En las primeras Escuelas de Arquitectura norteamericanas se vivía de los conocimientos originados en Europa, siguiendo el método beaux-artiano de origen francés. Se importaban profesores y se enviaba a los mejores alumnos becados para que terminaran sus estudios en París y se empaparan de su cultura. La estructura de talleres se estableció de manera general en todas las escuelas americanas.
Fig. 2. Walter Gropius con alumnos en Harvard en 1946.

Fig. 3. César Ortiz-Echagüe, Mies van der Rohe y Manuel Barbero en su viaje a los Estados Unidos. Archivo Universidad de Navarra.

Asuntos Exteriores, the Instituto Técnico de la Construcción y del Cemento, the Ministerio de Educación y Ciencia, and other organizations from the Spanish Public Administration.

The Education of the Architect. Among all the trips that Spanish architects made to the USA, we can highlight those to study at American universities. Those enrolled were already architects, but they decided to complete their formation on a specific topic, taking advantage of the high level of American education in some fields. In this article, we discuss the university teaching in Spain and the USA at that moment. Then we enumerate some of the trips that architects made in the 50s.

The training of architects at Schools of Architecture started more or less at the same time in Spain and the USA in the middle of the 19th Century. The School of Madrid opened its doors in 1844, and the one in Barcelona opened in 1875. They were the only schools until 1960 when the School of Sevilla opened. In the USA, the first schools of architecture, all of which were private, were at MIT (1865), Cornell University (1871), and at the University of Illinois (1873). Before the start of the 20th Century, the USA had eleven schools of architecture. In 1897, the first law on the register of architects in Illinois appeared. Until then, there was no entity to supervise the education, formation, and competence of architects.

The firsts American schools of architecture followed European teaching methods, the French Beaux-Arts. They hired European professors, and they granted the best students to finish their studies in Paris. The structure of workshops was established in every American school of architecture. 
En un segundo plano, ya avanzado el siglo xx, fueron surgiendo escuelas con métodos docentes alternativos alrededor de algunas de las principales figuras de la arquitectura. Frank Lloyd Wright abrió Taliesin Fellowship en 1932 (2) y Eliel Saarinen dirigió la Escuela de Arquitectura de Cranbrook Academy of Art entre 1932 y 1950. (3)

Al ponerse al frente de la Escuela de Arquitectura de Columbia University en 1933, Joseph Hudnut planteó un nuevo currículum en el que se ve el comienzo de un cambio. En este currículum planteaba la necesidad de responder a las tres principales responsabilidades del arquitecto: "enseñar la ciencia de la construcción, explicar las corrientes económicas e intelectuales en que vive el alumno y alentar la creación de belleza”. (4) Después de dos años, en los que no le dio tiempo a ver los resultados de dicho plan, renunció para pasar a ocupar el puesto de decano de la Graduate School of Design en Harvard, siendo un personaje fundamental para el fichaje de arquitectos europeos como profesores.

La llegada de los emigrados europeos: Walter Gropius, Mies van der Rohe, Marcel Breuer, Ludwig Hilberseimer, Eric Mendelsohn o Martin Wagner entre otros a puestos docentes en varias universidades americanas propició un cambio de rumbo hacia la modernidad. (Figs. 2 y 3 ) Sus nuevos programas, junto con los que implantaron arquitectos americanos como W. W. Wurster en el MIT (1944) y en Berkeley (1950 y 1959), dejaron atrás los antiguos métodos y lanzaron la educación norteamericana al puesto destacado que mantiene aún hoy. (5)

En España en ese momento (hasta 1956) seguían vigentes los cursos preparatorios y el exigente examen de ingreso. En los años 20 se había pasado de la influencia del sistema Beaux-Arts a la entrada de la cultura técnica alemana, basada en el rigor de los procesos científicos, (6) pero esta corriente tuvo una breve duración y escasa repercusión. Después de la Guerra Civil, la enseñanza en las Escuelas tanto de Madrid como de Barcelona estaba "centrada en el arte y la ciencia”. (7) Salvo muy raras excepciones no se hablaba de la modernidad, estando la mayoría de las asignaturas basadas en criterios historicistas. La escasez de los viajes al extranjero, la reducida difusión de las revistas de arqui-

Later in the 20th Century, schools with alternative methods of education appeared, usually around some of the masters of architecture. Frank Lloyd Wright opened the Taliesin Fellowship in 1932 (2) and Eliel Saarinen was Dean of the School of Architecture of the Cranbrook Academy of Art between 1932 and 1950. (3)

When Joseph Hudnut became Dean of the School of Architecture at Columbia University in 1933, he introduced a new curriculum in which we can see the start of a change. He presented in his plan the need to answer three main questions about the architect's role: "whether the schools may teach construction science, the intellectual and economic currents in which the student is living, and to encourage the creation of beauty". (4) After two years in which he could not see the results of this curriculum, he resigned and became Dean of the Graduate School of Design at Harvard, where he was a key person in the recruitment of European architects as professors.

The arrival of the European emigrants Walter Gropius, Mies Van der Rohe, Marcel Breuer, Ludwig Hilberseimer, Eric Mendelsohn, and Martin Wagner among others favoured a change in the direction of modernity. (Figs. 2 and 3) Their new programs, together with those implemented by American architects such as W. W. Wurster at MIT (1944) and Berkeley (1950 and 1959), (5) left behind the old methods and launched American education to the prominent position that it still maintains today.

In Spain at that time (until 1956), to access the School of Architecture, students had to pass a difficult exam for which they prepared for years. In the 20s, the educative methods changed from a Beaux-Arts system to one influenced by the 
tectura moderna y su desconocimiento por parte de los profesores hacían que la enseñanza que se recibía en la escuela tuviera poco que ver con el inconformismo y la necesidad de conocer las novedades que manifestaban algunos de los alumnos aventajados.

También había grandes diferencias en cuanto a recursos económicos y tecnológicos entre ambos países. La industria de la construcción en Estados Unidos se había desarrollado enormemente gracias a la traslación de muchos de los avances logrados durante la guerra a este ámbito. En España, la situación de aislamiento internacional y la escasez de la posguerra provocaron que se utilizaran principalmente los materiales tradicionales, más disponibles.

Esta era la situación en la que habían sido formados los arquitectos españoles, por un lado, y la que se encontraron al viajar a Estados Unidos para completar sus estudios, por otro. Fue el atisbar las posibilidades de aprendizaje que les ofrecía la estancia en Estados Unidos lo que hizo que se lanzaran a aprovechar las oportunidades que se les presentaban. A continuación, vamos a dar algunas pinceladas sobre varios de ellos, con el riesgo de simplificarlos superficialmente, pero con la intención de dar una visión de conjunto.

José Subirana Rodríguez (ETSAM 1939) fue becado por la Fundación del Amo para realizar estudios de planeamiento urbanístico en la Universidad de Berkeley durante seis meses, a partir de febrero de 1949.

Según se recoge en su correspondencia con la Fundación, no fueron tan importantes sus estudios como los contactos profesionales y las investigaciones que desarrolló alrededor de los temas de su interés. (8) Durante su estancia estuvo en contacto con varios de los mejores arquitectos que había en California en ese momento (Richard Neutra, Charles O. Mateham, Robert E. Alexander, H. Roy Kelley, Adrian Wilson, Paul R. Williams, Whitney Smith, Simon Eisner, M. Russell o Eduardo Samaniego), los cuales le invitaron a visitar sus estudios e incluso le acompañaron a conocer algunas de sus obras. (9)

German technical culture based on scientific processes, (6) but this trend had a short duration and small repercussions. After the Spanish Civil War, the teaching in the schools of architecture in both Madrid and Barcelona were "centred in Art and Science". (7) It was difficult to hear about the Modern Movement, and most of the subjects were based on historical concepts. Due to the scarcity of the trips to foreign countries, the limited diffusion of the Modern Architecture reviews, and the ignorance of some professors, the education that the students were receiving had almost nothing to do with the non-conformism and the need to know of novelties that some of the outstanding students had.

At the same time, there was a big difference between the economic and technological resources of both countries. The construction industry in the US had been enormously developed thanks to the research achieved during World War II. In Spain, the situation of international isolation and the scarcity of the post-war caused the traditional materials to be frequently used.

That was the situation of the education of the Spanish architects and the situation they had when they came back after completing their studies in the USA. They saw the possibilities of learning opened by a stay in America, and they decided to take advantage of the opportunity. In the next section, we provide some hints about some of them aware of the risk of a simplification but with the intention of giving an overview.

José Subirana Rodríguez (ETSAM 1939) was granted by the Fundación del Amo to study urban planning at the University of Berkeley for six months starting in February 1949. 
Se interesó principalmente por el problema del aparcamiento de vehículos y por cómo esta cuestión condicionaba el planeamiento de las ciudades. Para ello se puso en contacto con las principales entidades públicas y privadas que gestionaban los aspectos políticos, los transportes públicos y la planificación urbana. Recopiló gran cantidad de documentación que comenzó a revisar desde allí y terminó a su vuelta a Madrid.

Fernando Chueca Goitia (ETSAM 1936) se presentó y ganó en 1951 la convocatoria de la beca Conde de Cartagena, de la Real Academia de Bellas Artes de San Fernando, para realizar una estancia en los Estados Unidos. A ella se presentaron también otros siete jóvenes arquitectos, entre ellos José Luis Picardo, José María García de Paredes y Alejandro de la Sota.

La estancia se prolongó desde el mes de mayo de 1951 hasta abril de 1952. Ocho meses sufragados por la beca y tres meses más por su cuenta. Eligió como destino la ciudad de Nueva York, capital norteamericana por excelencia, desde donde pudo visitar otras ciudades. Viajó acompañado por su mujer. Los frutos de su estancia se concretaron en dos publicaciones y una memoria presentada a su vuelta en la Academia. (Figs. 4 y 5 )
Figs. 4 y 5. Dibujos realizados por Fernando Chueca Goitia y publicados en su libro Nueva York, forma y sociedad.
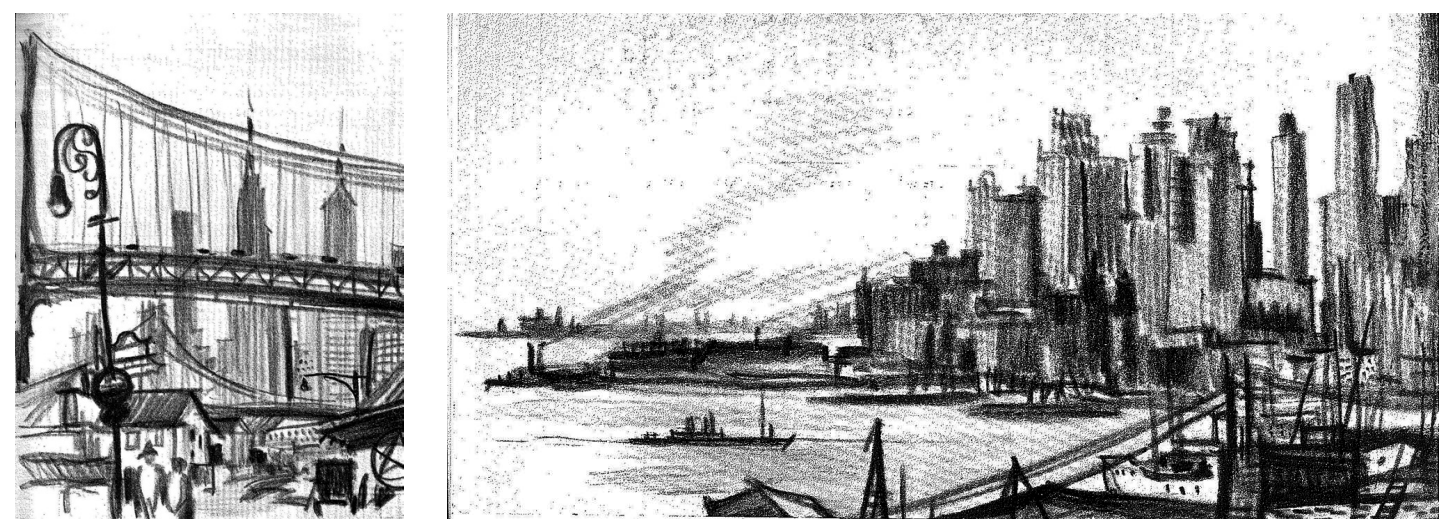

As he left written in his correspondence with the Foundation, the professional contacts he made and the research he did on the topics he was interested in were more important than his formal studies at the university. (8) During his stay in the USA, he met some of the best architects that were living in California at the time (Richard Neutra, Charles O. Mateham, Robert E. Alexander, H. Roy Kelley, Adrian Wilson, Paul R. Williams, Whitney Smith, Simon Eisner, M. Russell or Eduardo Samaniego), some of whom invited him to visit their offices and works. (9)

He was interested in the problem of car parking and how this affected the urban planning of cities. He was in touch with the main public and private companies involved in the political aspects, public transportation, and urban planning. He obtained a large number of documents that he began to study in the USA and finished in Madrid. (10)

Fernando Chueca Goitia (ETSAM 1936) won, in 1951, the Conde de Cartagena grant from the Real Academia de Bellas Artes de San Fernando, which allowed him to stay in the USA. Seven other young architects aimed for it including José Luis Picardo, José María García de Paredes, and Alejandro de la Sota.

He was in America from May 1951 to April 1952. The grant supported eight months stay, and he paid for three more himself. He chose New York City, the American city par excellence, but he travelled to other cities. He was there with his wife. After this stay, he compiled what he learned, published books, and presented a memoir to the Real Academia. (Figs. 4 and 5) 
Buscó adquirir un conocimiento general de la cultura, la sociedad americana, el país y sus problemas. En primer lugar, estudió urbanismo y sociología en la Universidad de Columbia, gracias a lo cual pudo conocer de primera mano la educación de un arquitecto en Estados Unidos, además de acceder a diferentes bibliotecas y archivos. Por otro lado, y debido a su cargo como arquitecto de la Fundación Lázaro Galdiano, estudió los museos de arte y otras instituciones culturales, desde el punto de vista arquitectónico.

Además, visitó Washington, Boston, Filadelfia, Williamsburg y Chicago, dejando reflejadas en las memorias sus interesantes opiniones sobre cada una de estas ciudades.

Rafael de la Hoz Arderius (ETSAM 1951) era arquitecto de la Diputación de Córdoba y había llevado a cabo diseños reseñables como la Cámara de Comercio de Córdoba o la tienda de Vogue en la misma ciudad cuando, en 1955, consiguió una beca como pensión de estudios para participar en programa de verano para estudiantes internacionales en el Massachusetts Institute of Technology. (11)

Esta estancia incentivó su interés por la cultura americana: "su interés por la técnica le llevó a admirar la eficacia constructiva americana y a estudiar la manera de elevar la calidad de la construcción respetando unos mínimos de estandarización y normalización tecnológica”. (12) Se matriculó de cuatro asignaturas: Plásticos en el diseño de productos para la edificación, Planeamiento urbano y regional, Códigos de edificación de colegios en Estados Unidos e Investigación de problemas en planificación de hospitales. (13)

Valentín Picatoste Patiño (ETSAM 1954) accedió a la beca Eisenhower para líderes mundiales gracias a la cual pasó diez meses en Estados Unidos, en 1958, para estudiar temas relacionados con el urbanismo, la arquitectura y el sistema de enseñanza americano. (14) Había colaborado recientemente en la oficina de proyectos americana que llevó a cabo la construcción de las



Fig. 6. Lake Shore Drive Apartments en Chicago, de Mies van der Rohe y una visión de Nueva York. Fotografías publicadas por Chueca Goitia.

He wanted to acquire general knowledge about the American culture, society, the country, and its problems. Firstly, he studied urbanism and sociology at Columbia University thanks to which he knew first-hand about the education of architects in the States, and he had access to the University's archives and libraries. Secondly, and because he was the architect of the Lázaro Galdiano Foundation, he studied the art museums and some other cultural institutions from the architectural point of view. He also visited Washington, Boston, Philadelphia, Williamsburg, and Chicago, leaving his opinion on each of these cities in the memoir.

Rafael de la Hoz Arderius (ETSAM 1951) was an architect employed at the Córdoba Public Administration, and he had already designed buildings like the Cámara de Comercio or the Vogue store in the same city, when, in 1955, he won a scholarship to participate in a summer course for international students at MIT. (11)

This stay increased his interest in the American culture: "His interest in the technical aspects made the American constructive efficacy interesting to him, and he studied the way to increase the quality in construction while keeping minimum standards in technology". (12) He took four subjects: Plastics in the Design of Products for Construction, Urban and Regional Planning, Building Codes for Schools in the US, and Research in Problems of Hospital Designs. (13)

Valentín Picatoste (ETSAM 1954) won the Eisenhower Grant for World Leaders, and he spent ten months in the USA in 1958 studying topics about urbanism, architecture, and the American educational system. (14) He had recently worked 
bases militares en territorio español, por lo que ya estaba familiarizado con los métodos y materiales norteamericanos.

Allí pudo contactar con varios de los principales arquitectos modernos establecidos en Estados Unidos y también pudo visitar sus edificios (Figs. 6 y 7): Eero Saarinen, Mies van der Rohe, Pietro Belluschi, Walter Gropius, Ludwig Hilberseimer, Louis I. Kahn, Frank Lloyd Wright o Josep Lluís Sert. También conoció desarrollos urbanos, de viviendas y de rehabilitación a gran escala, gracias a la colaboración de la Public Housing Administration. (15)

Procedente de Gijón, Mariano Marín Rodríguez Rivas (ETSAM 1957) se tituló en 1957 y al año siguiente marchó a EE. UU. para realizar estudios de posgrado (el máster en arquitectura) en el Massachusetts Institute of Technology durante los cursos 1958-1959. Solicitó para ello una de las becas Fulbright. En Boston pudo conocer las enseñanzas de Pietro Belluschi, Walter Gropius, Josep Lluís Sert y profesores invitados como Ludovico Quaroni, además de alimentar su interés por la cultura, la literatura y la música americanas. (16) Su tesis de fin de máster del MIT tenía como título La Iglesia del Santo Sepulcro de Jerusalén. (17)

El gallego Desiderio Pernas Martínez (ETSAM 1958) también pudo disfrutar de una de las primeras becas Fulbright para estudiar en el Illinois Institute of Technology, durante los años 1958-59, inmediatamente después de acabar la carrera. (18) Aunque no fue alumno de Mies van der Rohe, ya retirado, quedó realmente marcado por su enseñanza y por la arquitectura del maestro, como se apreciará en su obra posterior. Pudo seguir el plan de estudios diseñado por él para la Escuela de Arquitectura.

Juan Antonio Ridruejo Brieva (ETSAM 1959) estuvo durante dos años en Harvard, desde 1959, realizando un máster de Planeamiento Urbano. Su mujer también asistió allí a algunos cursos de diseño, aunque no se graduó. (19) Después, durante un año, estuvo como profesor en la Universidad de

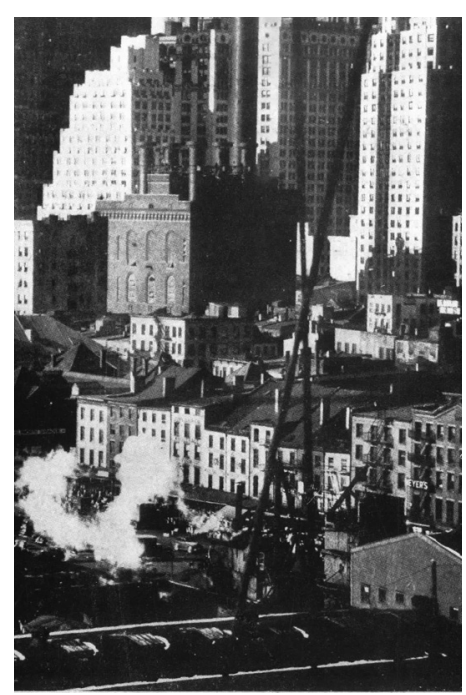

Fig. 7. Lake Shore Drive Apartments en Chicago, de Mies van der Rohe y una visión de Nueva York. Fotografías publicadas por Chueca Goitia.

with the American Projects Office in the construction of the military bases in Spain, so he was already used to the American methods and materials.

He contacted some of the most important architects who lived in the USA and visited their buildings (Figs. 6 and 7) including Eero Saarinen, Mies van der Rohe, Pietro Bellusqui, Walter Gropius, Ludwig Hilberseimer, Louis I. Kahn, Frank Ll. Wright, and Josep Lluís Sert. He also visited urban developments, housing, and rehabilitation projects thanks to the collaboration of the Public Housing Administration. (15)

Mariano Marín Rodríguez Rivas (ETSAM 1957) was from Gijón. One year after graduating as an architect, he moved to the USA to enter a post-graduate program at MIT in 1958-59. He applied for and obtained a Fulbright Grant. In Boston, he taught under Pietro Belluschi, Walter Gropius, Josep Lluís Sert, and visiting professors such as Ludovico Quaroni. (16) He also studied American culture, literature, and music. His Master's Thesis was titled The Church of the Holy Sepulchre in Jerusalem. (17)

Desiderio Pernas Martínez (ETSAM 1958) was Galician, and he enjoyed one of the first Fulbright Grants to study at the Illinois Institute of Technology in 1958-59 just after finishing his degree. (18) He was not a student of Mies van der Rohe, who had already retired, but his teaching and buildings left an imprint in Pernas, as can be seen in his work. He followed the curriculum designed by Mies for master's students. 
California en Berkeley. (20) A su vuelta a España, dio clase en la Escuela de Madrid. También realizó el proyecto de urbanización de la Moraleja, en el que se podría vislumbrar cierta referencia a los conjuntos urbanos de lujo de grandes dimensiones vistos en Norteamérica.

Miguel de Oriol e Ybarra (ETSAM 1959) había oído hablar de Frank Lloyd Wright antes de comenzar la carrera gracias a un libro que le regaló su padre. Y fue su conocimiento lo que le impulsó a ser arquitecto. (21) Se sintió atraído por el urbanismo durante sus estudios en la Escuela de Arquitectura al oír hablar científicamente del tema; y esto le llevó a optar por una beca Fulbright, que le fue concedida en 1960 para realizar un máster en Planeamiento Urbano en la Universidad de Yale. (22)

Le llamó mucho la atención el clima intelectual de la universidad americana y las posibilidades que se le abrían de desarrollar su propio pensamiento:

"El clima de competencia y emulación que allí encontré me hizo echar toda la carne al asador, poniéndome realmente en juego. Se nos suministraba una inmensa información-conferencias y bibliotecas- en la que uno llegaba a donde podía. Las conferencias eran de los mejores especialistas en cada materia del mundo. La biblioteca era la segunda de las universitarias, también a escala universal -la primera estaba al lado y era la de Harvard-. Los conferenciantes, además de pensar, no recitar, delante de nosotros guiaban nuestras lecturas. Y después nos daban un plazo para que nosotros meditáramos sobre lo que habíamos leído y expusiéramos nuestra opinión. ¡Teníamos opinión!, así que había que crearla. Leíamos y pensábamos (En España como no nos la pedían, la improvisábamos y, naturalmente, destruía cualquier planteamiento previo para ser oída)". (23)

Tuvo allí profesores destacados como Josep Lluís Sert, Louis I. Kahn, Craig Ellwood, Paul Rudolph, Vincent Scully o Christopher Tunnard. Deseoso de aprovechar la oportunidad que se le estaba brindando, estudiaba día y noche para construir su propia opinión. También aprovechó para conocer Nueva

Juan Antonio Ridruejo (ETSAM 1959) was working on a Master's degree in Urban Planning for two years at Harvard starting in 1959. His wife followed some design courses there as well, though she did not graduate. (19) After that, he was a professor at the University of California at Berkeley for one year. (20) Back in Spain, he taught at the School of Architecture of Madrid. He designed the urban project for La Moraleja in which we can find references to the wealthy American suburbs.

Miguel de Oriol e Ybarra (ETSAM 1959) had heard about Frank Lloyd Wright before starting the degree thanks to a book that his father gave to him. That was crucial in his decision to become an architect. (21) He was interested in urbanism during his studies in Madrid, and he wanted to learn about the scientific point of view of this topic. He applied for and won a Fulbright Grant to enroll in the Master in Urban Planning program at Yale University. (22)

He liked the intellectual climate of the American university and the possibilities that it provided to develop his own way of thinking:

"The climate of competition and emulation that I found there made me give the best of myself and to play that game. The university gave us a huge amount of information -lectures and libraries- in which each one did the best he could. The lectures were given by the world best specialists on each topic. The library was the second most important, after Harvard, also next to us. The lecturers did not recite, they guided our readings. And after that, they gave us some time to think about what we had 




York, Boston, New Haven y New Canaan, donde visitó las viviendas de Marcel Breuer y Philip Johnson.

Conclusiones. Como hemos visto, una gran mayoría de los arquitectos españoles que realizaron estancias de formación en Estados Unidos se decantaron por estudios de urbanismo y planeamiento. Estos estudios, que en España eran de reciente creación (no aparece una asignatura de Urbanismo como tal en el Plan de Estudios de la Escuela de Madrid hasta 1932), en Estados Unidos tenían un gran desarrollo, forzado por la necesidad de planificar nuevas ciudades con gran velocidad de crecimiento. (Fig. 8)

Algunos de estos arquitectos, a su regreso a España, desarrollaron su propia labor docente en las Escuelas de Arquitectura. La huella que pudo haberles dejado ese paso por EE. UU. se transmitía a sus alumnos. Cabe destacar sus
Fig. 8. Trabajos realizados por los alumnos de Urban Planning de Columbia University, 1954.

read and to express our opinion. We had an opinion, so we had to create it. We read and we thought. In Spain, no one asked about our opinion, so we improvised and, of course, we destroyed any previous right to be heard". (23)

He had very good professors such as Josep Lluís Sert, Louis I. Kahn, Craig Ellwood, Paul Rudolph, Vincent Scully, or Cristopher Tunnard. He wanted to take advantage of the situation, so he studied day and night to build his own opinion. He visited New York, Boston, New Haven, and New Canaan, where he visited the houses of Marcel Breuer and Philip Johnson.

Conclusions. As we have seen in this article, most of the architects who went to study in the USA decided to learn more about urbanism and planning. This kind of knowledge that started to be taught in Spanish schools of architecture relatively late (there was no subject like Urbanism in the School of Madrid until 1932), had a big development in the USA because of the need to plan new cities without much time. (Fig. 8)

When some of these architects came back to Spain, taught as professors in the schools of architecture. The footprint left on them by their stay in the USA was transmitted to their students. We can highlight their analysis of the differences between both educative methods and how they tried to implement in Spain their positive findings in the USA.

Fernando Chueca Goitia (24) considered the American tradition of the students paying for their studies very positive because it encouraged them to be responsible for their learning, and they made the most of it. As a result, attendance to 
análisis sobre las diferencias entre ambos métodos educativos, orientados a potenciar aquí los aspectos positivos encontrados en la educación de allí.

A Fernando Chueca Goitia (24) le pareció muy positiva la costumbre de EE. UU. de que los alumnos se pagaran su propia enseñanza, lo que fomentaba que se hicieran responsables de su aprendizaje y lo aprovecharan al máximo. Esto se reflejaba en la asistencia a clase y también en la exigencia al profesor. Se les facilitaba a los alumnos simultáneamente una formación técnica y práctica, colaborando con ingenieros y técnicos. Muchos de los futuros arquitectos, para financiar sus estudios, trabajaban mientras los hacen como delineantes o ayudantes.

Es curioso cómo destacaba también la moralidad americana: "la vida universitaria en América tiene un gran fondo de moralidad. Si se copiaran unos a otros, les faltaría luego el conocimiento real de su preparación al terminar el curso, y esto es lo que principalmente les interesa y lo que piden al profesor". (25) También le llaman la atención los trabajos escritos, papers, trabajos de investigación realizados a lo largo del curso en las diferentes materias. En resumen, lo que destaca principalmente es la implicación real del alumno en su propia educación y la importancia que da a su aprendizaje, no a la consecución de un título.

Son todos ellos aspectos que, junto con el aprendizaje en primera persona al lado de algunos de los grandes maestros en arquitectura del momento, hicieron que estos arquitectos volvieran a España cargados de imágenes de arquitectura moderna y de conocimientos que después transmitieron a otras generaciones, además de aplicarlos en su obra construida.

Hoy en día siguen siendo constantes los viajes de arquitectos al otro lado del Atlántico. La frecuencia y el coste de las oportunidades han cambiado, y la globalización, el desarrollo de las comunicaciones y el considerable avance económico de España han conseguido que el impacto al conocer el Nuevo Mundo se reduzca. También el desarrollo de otras potencias mundiales ha relativizado la importancia de los Estados Unidos. No obstante, el mito se mantiene en muchos aspectos, entre ellos el prestigio de sus Universidades.

classes and demands on the professors rose. It was normal for the students to have a technical, theoretical, and practical formation at the same time. Many of the future architects were working as draftsmen or assistants while studying.

He emphasized American morality: "The university life in the States is deeply moral. If they copied someone else's work, they would not know what their real knowledge is when finishing the course, and this is exactly what they are interested in and they demand it from the professor". (25) He also liked the research papers written during the studies. Summing up, he underlined the real implication of the students in his education and the importance they gave to the knowledge they acquired, not to the academic qualification.

All of these aspects, together with learning close to some of the great masters in the architecture of that time, made these architects return to Spain with an abundance of knowledge and images about Modern Architecture that they applied in their work and their teaching and transmitted to the following generations.

In the present day, it is still common to travel across the Atlantic. The frequency of the trips and the cost of the opportunities have changed, and the globalization and development of the communications as well as the economic progress of Spain have reduced the impact of meeting the New World. The development of new world powers has minimized the importance of the USA. However, the myth is still alive in a lot of aspects such as the prestige of their universities. 


\section{NOTAS}

1. Entrevista a Bernardo Yncenga, 20 de noviembre de 2014

2. "Wright's earlier organization at his Oak Park Studio had much more resembled the Bauhaus. His talented assistants there were paid for an active role in his practice and $\mathrm{W}$ right delegated responsibilities including meetings with clients. At Taliesin almost no apprentice was given any significant responsibility. A critical stance would not be tolerated. The Oak Park Studio produced quality architects, Taliesin very few". JONES, Michael Anthony. Models for educating architects in this century and the next. Tesis doctoral inedita, Georgia Institute of Technology, 1989, p. 261.

3. "Eliel Saarinen believed that every one of his students should receive dedicated, individual attention, for it was only in this manner that the ideals, philosophy and methods of approach he had developed during his years in architecture could be absorbed by them. He was never dogmatic either in his architecture or teaching, and he reserved the right to change his mind or modify his ideas as the times dictated". Ibidem, p. 262. 4. HUDNUT, Joseph. 'The Education of the Architect'. Architectural Record, mayo, 1931, p. 412.

5. "At MIT from 1944-50, Wurster's recruitment included Gyorgy Kepes, Henry-Russell Hitchcock (1903-1987), Ralph Rapson (1934-), and Kevin Lynch. On arrival, Wurster found the MIT faculty ideologically split. With judicious hiring and firing he not only achieved divergent opinions in architecture and city-planning, but also a staff which operated as a cohesive unit. There was no dogma, no idealistic, single position". JONES, M. A. Ibidem, p. 279.

6. AA.VV. Centenari de L'Escola D'Arquitectura de Barcelona 187576/1975-76. Barcelona: Escuela Técnica Superior de Arquitectura de Barcelona, 1977, pp. 324-325.

7. SAÉNZ DE OÍZA, Francisco Javier. Escritos y conversaciones.

Barcelona: Fundación Caja de Arquitectos, 2006, p. 120.

8. Además, procuró conocer la cultura americana, como refleja en la correspondencia a la Fundación del Amo: "Besides these activities I have made various visits to stores, theatres, auditoriums, stadiums, libraries, museums, planetariums, expositions, universities, stores and homes in which there is so much to learn in this great city of Los Angeles".

SUBIRANA, José. 'Carta a la Fundación del Amo en mayo 1949'. Archivo Fundación del Amo, caja 75, carpeta 8, Subirana, José L. 1948-1949.

9. Ibidem.

10. Ibidem.

11. AA. VV. 'Rafael de la Hoz, pensionado en EE. UU' Boletín Dirección General de Arquitectura,1955, tercer trimestre.

12. DÍEZ MEDINA, Carmen. 'Tras las huellas de América en España: un breve rastreo. En: AA.VV. La arquitectura norteamericana, motor y espejo de la arquitectura española en el arranque de la modernidad (1940-1965). Pamplona: T6 Ediciones, 2006, p. 114

13. Base de datos del MIT.

14. BILBAO, Luis. 'El debate en torno a la influencia de la arquitectura estadounidense en España: Los arquitectos Luis Vázquez de Castro, Valentín Picatoste y las memorias de los técnicos españoles en Estados Unidos'. En: AA.VV. La arquitectura norteamericana, motor y espejo de la arquitectura española en el arranque de la modernidad (1940-1965). Pamplona: Universidad de Navarra, 2006, p. 82.

15. Ibidem, p. 84.

16. ALONSO PEREIRA, José Ramón; RÍO VÁZQUEZ, Antonio $S$. 'Viajes entre Roma y Massachusetts: Experiencias paralelas de sendos arquitectos de Galicia y de Asturias durante los años cincuenta?. En: AA.VV. Viajes en la transición de la arquitectura española hacia la modernidad. Pamplona: Universidad de Navarra, 2010, p. 93. 17. Base de datos del MIT.

18. Ibidem.

19. Base de datos de la Universidad de Harvard.

20. ESTEBAN MALUENDA, Ana. La modernidad importada. Madrid 1949-1968: Cauces de difusión de la arquitectura extranjera. Tesis doctoral inédita, Universidad Politécnica de Madrid, 2007. Entrevista a Bernardo Yncenga, pp. 663-669.

\section{NOTES}

1. Personal interview with Bernardo Yncenga, 20 November 2014.

2. "Wright's earlier organization at his Oak Park Studio had much more resembled the Bauhaus. His talented assistants there were paid for an active role in his practice and Wright delegated responsibilities including meetings with clients. At Taliesin, almost no apprentice was given any significant responsibility. A critical stance would not be tolerated. The Oak Park Studio produced quality architects, Taliesin very few". JONES, Michael Anthony. Models for educating architects in this century and next. Unpublished Doctoral Thesis, Georgia: Institute of Technology, 1989, p. 261.

3. "Eliel Saarinen believed that every one of his students should receive dedicated, individual attention, for it was only in this manner that the ideals, philosophy and methods of approach he had developed during his years in architecture could be absorbed by them. He was never dogmatic either in his architecture or teaching, and he reserved the right to change his mind or modify his ideas as the times dictated". Ibidem, p. 262. 4. HUDNUT, Joseph. 'The Education of the Architect'. Architectural Record, 1931, May, p. 412.

5. "At MIT from 1944-50, Wurster's recruitment included Gyorgy Kepes, Henry-Russell Hitchcock (1903-1987), Ralph Rapson (1934-), and Kevin Lynch. On arrival, Wurster found the MIT faculty ideologically split. With judicious hiring and firing, he not only achieved divergent opinions in architecture and city planning, but also a staff which operated as a cohesive unit. There was no dogma, no idealistic, single position". JONES, Michael Anthony. Ibidem, p. 279.

6. AA.VV. Centenari de L'Escola D'Arquitectura de Barcelona 187576/1975-76. Barcelona: Escuela Técnica Superior de Arquitectura de Barcelona, 1977, pp. 324-325.

7. SAÉNZ DE OÍZA, Francisco Javier. Escritos y conversaciones.

Barcelona: Fundación Caja de Arquitectos, 2006, p. 120.

8. Moreover, he tried to know the American culture, as shown in his letters to Fundación del Amo: "Besides these activities, I have made various visits to stores, theatres, auditoriums, stadiums, libraries, museums, planetariums, expositions, universities, stores and homes in which there is so much to learn in this great city of Los Angeles". In SUBIRANA,

José. 'Carta a la Fundación del Amo en Mayo 1949'. Fundación del Amo Archive, box 75, folder 8, Subirana, José L. 1948-1949.

9. Ibidem.

10. Ibidem.

11. AA. VV. 'Rafael de la Hoz, pensionado en EE. UU.' Boletín Dirección General de Arquitectura, 1955, Third term.

12. DÍEZ MEDINA, C.'Tras las huellas de América en España: un breve rastreo'. In: AA. VV. La arquitectura norteamericana, motor y espejo de la arquitectura española en el arranque de la modernidad (1940-1965). Pamplona: T6 Ediciones, 2006, p. 114.

13. MIT Database.

14. BILBAO, Luis. 'El debate en torno a la influencia de la arquitectura estadounidense en España: Los arquitectos Luis Vázquez de Castro,

Valentín Picatoste y las memorias de los técnicos españoles en Estados Unidos. En: AA.VV. La arquitectura norteamericana, motor y espejo de la arquitectura española en el arranque de la modernidad (1940-1965). Pamplona: Universidad de Navarra, 2006, p. 82.

15. Ibidem, p. 84.

16. ALONSO PEREIRA, José Ramón; RÍO VÁZQUEZ, Antonio

S. 'Viajes entre Roma y Massachusetts: Experiencias paralelas de sendos arquitectos de Galicia y de Asturias durante los años cincuenta'. In: AA.VV. Viajes en la transición de la arquitectura española hacia la modernidad. Pamplona: Universidad de Navarra, 2010, p. 93.

17. MIT Database.

18. Ibidem.

19. Harvard University Database.

20. ESTEBAN MALUENDA, Ana. La modernidad importada. Madrid 1949-1968: Cauces de difusión de la arquitectura extranjera. Unpublished Doctoral Thesis, Universidad Politécnica de Madrid, 2007. Interview with Bernardo Yncenga, pp. 663-669. 
21. ALARCÓN, Candelaria. La arquitectura en España a través de las revistas especializadas 1950-1970. El caso de Hogar y Arquitectura. Tesis doctoral inédita, Universidad Politécnica de Madrid, 1999. Entrevista a Miguel de Oriol e Ybarra. Anexo E, p. 28.

22. ORIOL e YBARRA, Miguel de. Ser arquitecto. Madrid: Fundación Universidad-Empresa, 1987, p. 42.

23. Ibidem.

24. CHUECA GOITIA, Fernando. 'Experiencias arquitectónicas de un viaje a Norteamérica. Sesión crítica de Arquitectura'. Revista nacional de arquitectura, n. 135. Madrid: DGA, 1953.

25. Ibidem, p. 39.

\section{REFERENCIAS}

AA.VV. Centenari de L'Escola D'Arquitectura de Barcelona 187576/1975-76. Barcelona: Escuela Técnica Superior de Arquitectura de Barcelona, 1977.

AA.VV. 'Rafael de la Hoz, pensionado en EE. UU.. Boletín Dirección General de Arquitectura. 1955, tercer trimestre.

ALARCÓN, Candelaria. La arquitectura en España a través de las revistas especializadas 1950-1970. El caso de Hogar y Arquitectura. Tesis doctoral inédita, Universidad Politécnica de Madrid, 1999.

ALONSO PEREIRA, José Ramón; RÍO VÁZQUEZ, Antonio S. 'Viajes entre Roma y Massachusetts: Experiencias paralelas de sendos arquitectos de Galicia y de Asturias durante los años cincuenta?. En: AA.VV. Viajes en la transición de la arquitectura española hacia la modernidad. Pamplona: Universidad de Navarra, 2010.

ÁLVARO MOYA, Adoración. Inversión directa extranjera y formación de capacidades organizativas locales: Un análisis del impacto de EE. UU. en la Empresa Española (1918-1975). Tesis doctoral inédita, Universidad Complutense de Madrid, 2011.

BILBAO, Luis. 'El debate en torno a la influencia de la arquitectura estadounidense en España: Los arquitectos Luis Vázquez de Castro, Valentín Picatoste y las memorias de los técnicos españoles en Estados Unidos'. En: AA.VV. La arquitectura norteamericana, motor y espejo de la arquitectura española en el arranque de la modernidad (1940-1965). Pamplona: Universidad de Navarra, 2006.

DÍEZ MEDINA, Carmen. 'Tras las huellas de América en España: un breve rastreo'. En: AA.VV. La arquitectura norteamericana, motor y espejo de la arquitectura española en el arranque de la modernidad (1940-1965). Pamplona: T6 Ediciones, 2006.

DRAPER, Joan. 'La École des Beaux-Arts y la profesión del arquitecto en los Estados Unidos: el caso de John Galen Howard'. En: AA.VV. El arquitecto: historia de una profesión. Madrid: Cátedra, 1984.

ESTEBAN MALUENDA, Ana. La modernidad importada. Madrid 19491968: Cauces de difusión de la arquitectura extranjera. Tesis doctoral inédita, Universidad Politécnica de Madrid, 2007.

HUDNUT, Joseph. 'The Education of the Architect'. Architectural Record, mayo, 1931.

JONES, Michael Anthony. Models for educating architects in this century and the next. Tesis doctoral inédita, Georgia Institute of Technology, 1989. ORIOL E YBARRA, Miguel de. Ser arquitecto. Madrid: Fundación Universidad-Empresa, 1987.

SAÉNZ DE OÍZA, Francisco Javier. Escritos y conversaciones. Barcelona: Fundación Caja de Arquitectos, 2006.

SUBIRANA, José. 'Carta a la Fundación del Amo en mayo 1949'. Archivo Fundación del Amo, caja 75, carpeta 8, Subirana, José L. 1948-1949.
21. ALARCÓN REYERO, Candelaria. La arquitectura en España a través de las revistas especializadas 1950-1970. El caso de Hogar y Arquitectura. Unpublished Doctoral Thesis, Universidad Politécnica de Madrid, 1999. Interview with Miguel de Oriol e Ybarra. Annexe E, p.28. 22. ORIOL e YBARRA, Miguel de. Ser arquitecto, Madrid: Fundación Universidad-Empresa, 1987, p. 42.

23. Ibidem.

24. CHUECA GOTIA, 'Experiencias arquitectónicas de un viaje a Norteamérica. Sesión crítica de Arquitectura'. Revista Nacional de Arquitectura, n. 135. Madrid: DGA, 1953.

25. Ibidem, p. 39.

\section{REFERENCES}

AA.VV. Centenari de L'Escola D'Arquitectura de Barcelona 187576/1975-76. Barcelona: Escuela Técnica Superior de Arquitectura de Barcelona, 1977.

AA.VV. 'Rafael de la Hoz, pensionado en EE. UU.. Boletín Dirección General de Arquitectura. 1955, Third Term.

ALARCÓN REYERO, Candelaria. La arquitectura en España a través de las revistas especializadas 1950-1970. El caso de Hogar y Arquitectura. Unpublished Doctoral Thesis, Universidad Politécnica de Madrid, 1999. ALONSO PEREIRA, José Ramón; RÍO VÁZQUEZ, Antonio S. 'Viajes entre Roma y Massachusetts: Experiencias paralelas de sendos arquitectos de Galicia y de Asturias durante los años cincuenta'. In: AA.VV. Viajes en la transición de la arquitectura española hacia la modernidad. Pamplona: Universidad de Navarra, 2010.

ÁLVARO MOYA, Adoración. Inversión directa extranjera y formación de capacidades organizativas locales: Un análisis del impacto de EE. UU. en la Empresa Española (1918-1975). Unpublished Doctoral Thesis, Universidad Complutense de Madrid, 2011.

BILBAO, Luis. 'El debate en torno a la influencia de la arquitectura estadounidense en España: Los arquitectos Luis Vázquez de Castro, Valentín Picatoste y las memorias de los técnicos españoles en Estados Unidos'. In: AA.VV. La arquitectura norteamericana, motor y espejo de la arquitectura española en el arranque de la modernidad (1940-1965). Pamplona: Universidad de Navarra, 2006.

DÍEZ MEDINA, Carmen. 'Tras las huellas de América en España: un breve rastreo'. In: AA. VV. La arquitectura norteamericana, motor y espejo de la arquitectura española en el arranque de la modernidad (1940-1965). Pamplona: T6 Ediciones, 2006.

DRAPER Joan. 'La École des Beaux-Arts y la profesión del arquitecto en los Estados Unidos: el caso de John Galen Howard'. In: AA.VV. $E l$ arquitecto: historia de una profesión. Madrid: Cátedra, 1984.

ESTEBAN MALUENDA, Ana. La modernidad importada. Madrid 19491968: Cauces de difusión de la arquitectura extranjera. Unpublished Doctoral Thesis, Universidad Politécnica de Madrid, 2007.

HUDNUT, Joseph. 'The Education of the Architect'. Architectural Record, May, 1931.

JONES, Michael Anthony Model for Educating Architects in this Century and Next. Tesis doctoral inédita, Georgia Institute of Technology, 1989. ORIOL e YBARRA, Miguel de. Ser arquitecto. Madrid: Fundación Universidad-Empresa, 1987.

SAÉNZ DE OÍZA, Francisco Javier. Escritos y conversaciones.

Barcelona: Fundación Caja de Arquitectos, 2006.

SUBIRANA, José. 'Carta a la Fundación del Amo en mayo 1949'. Archivo Fundación del Amo, caja 75, carpeta 8, Subirana, José L. 1948-1949. 
